\title{
DIE VEELSYDIGHEID VAN TOTIUS AS WETENSKAPLIKE
}

Die taak wat die Redaksie van Koers my gestel het, naamlik om 'n beeld te gee van prof. J.D. du Toit se veelsydigheid as wetenskaplike, is baie vleiend, maar ek betwyfel dit of een enkele sterfling, al het hy ook met watter oorgawe ál sy werke noukeurig deurgelees - deurgewerk selfs -, daaroor 'n oordeel kan vel en 'n samevatting kan gee.

Want in die eerste plek stel dit die eis dat 'n mens in jou gees 'n volledige oorsig moet hê van alle werke wat hy geskryf het, en ek kan dít nouliks doen ten opsigte van die rubrieke waarin ek hulle vir die nuwe Versamelde Werke $(N V W)$ verdeel het. Tweedens verwag dit van jou dat jy 'n oordeel moet kan vel en kan bepaal wat wetenskaplik houdbaar is en wat nie; en derdens moet jy ook die wetenskaplike gehalte daarvan bepaal.

Omdat ek my nie hiertoe bevoeg ag nie, gaan ek net poog om 'n soort inventaris op te stel, 'n oorsig te bied van die verskillende terreine wat hy met sy werke bestryk en net hier en daar 'n opinie te waag.

Wat wel van hom as wetenskaplike vasstaan, is dat hy gedurende die drie jaar wat hy in Nederland gestudeer het, dit met oorgawe gedoen het en móés doen. Dic laaste bewering maak ek op grond van die feit dat sy lcermeester, prof. A. Kuyper, aan hierdie jong Afrikaner in sy doktorale studie bykans bomenslike eise gestel het. Dit is byvoorbeeld bekend dat Kuyper van hom geverg het dat hy vir 'n tentamen in die Dogmatiek al die bewysplekke uit dic Skrif wat hy vir bepaalde stellings byhaal, nie maar net moes kon nocm of selfs in Nederlands moes kon siteer nie, maar hy moes hulle in Hebreeus en Grieks van buite geken het en kon siteer. Bowendien is van hom geëis dat hy die hele Nuwe Testament vers vir vers moes eksegetiseer.

Die feit dat hy in Nederland juis in hierdie tyd, 23 jaar na die ontstaan van die Vrije Universiteit, met lof kon promoveer, ge- 
tuig ondubbelsinnig van die hoë wetenskaplike waarde van sy proefskrif, Ilet Methodisme.

Van die nasionale en internasionale erkenning van sy geleerdheid getuig die agt eredoktorsgrade wat deur universiteite van die mees uiteenlopende aard en grondslag aan hom toegeken is. Hierdie erkenning berus gewis nie net op sy werk in verband met die Bybelvertaling of op sy digwerk nie. Eweneens is die feit dat die N.G. Kerk juis vir hom, 'n teoloog van die Gereformeerde Kerk, gevra het om in die saak teen prof. J. du Plessis as getuie vir die Kerk te verskyn, 'n sterk getuienis vir sy aansien en integriteit as geleerde.

Laastens moet ook genoem word dat hy tydens sy bykans veertig jaar lange diens as professor in the Teologie, waarin hy drie jaar lank die enigste dosent was, vyftien teologiese dissiplines gedoseer het en daarnaas ook nog in die Literariese Afdeling hulp verleen het, onder andere in Staatsfilosofie en Geskiedenis. Dit verklaar ten minste die wye spek trum van gebiede en onderwerpe wat hy met sy artikels, brosjures en werke van breëre opset bestryk. En hierby is dit merkwaardig hoc selde 'n mens by hom lees dat „iemand", „êrens" iets beweer het. Gewoonlik word bewerings met vers en kapittel gestaaf, en dit openbaar nie alleen sy belesenheid nie maar ook sy wetenskaplike ingesteldheid en gesindheid.

Naas die feit dat prof. Du Toit onder die skuilnaam Totius as digter bekend is, staan hy in ons land en daarbuite seker die wydste as Bybelvertaler bekend. Maar nou is dit ook waar dat Bybelvertaling vir hom meer behels het as net die oorsetting van Hebreeuse woorde en sinne in nou ooreenstemmende Afrikaanse woorde en sinne en die stilering daarvan, meer ook as eksegetisering van Skrifgedeeltes en bestudering van die kultuurhistoriese agtergrond van die Bybel. Hy het ook 'n diepgaande studie gemaak van die werk van ander vertalers (die Statevertalers, die vertalers van die King James-Bybel, Luther en ook die vertalers tydens ons eic Eerste Beweging); hy het hom rekenskap gegee van 
hulle probleme met die vertaling en daarmee rekening gehou, maar hy het ook die waarde van sodanige vertalings geweeg en die gocie en die verkeerde daarin onderskei en beoordecl. Dit word moontlik die beste gesien in sy instemmende aanhaling van 'n artikel van H.H. Kuyper in die Heraut oor die sogenaamde Leidse vertaling (NVW 1:132 e.v.).

Dit is seker ook waar dat sy instelling teenoor Bybclvertaling in 'n groot mate deur sy piëteit tcenoor die Bybel as die Woord van God bepaal is. Wat in hierdie verband tog merkwaardig is, is dat op drie kort artikels uit 1913 en 1914 na en die reeks van 1916 waarin hy verafrikaansing van die Statebybel bepleit, al sy stukke oor die Bybel as sodanig geskry $f$ is in die jare toe hy met vertaling en revisie besig was. En dit dui ook daarop dat hierdie gesigspunte hom voor die gees gesweef het terwyl hy met die vertaling en hersiening besig was. Dit openbaar weer sy wetenskaplike belangstelling in die werk wat hy verrig.

Die geskrifte wat hy oor die Bybel en die vertaling daarvan nagelaat het, beslaan nagenoeg 180 bladsye van die NVW en behels artikels oor die Bybel as die Woord van God, die gesag van die Heilige Skrif, die skoonheid van die Bybel, Skrifkritiek, geskiedskrywing in die Ou Testament, die Genootskap van Regte Afrikaners en die Bybelvertaling, procwe van Bybelvertaling, die vertaling van die Ou Testament in Afrikaans, die revisie van die Ou Testament soos in Afrikaans vertaal.

Ook die stukke wat onder Skrifverklaring in deel 1 van die NVW opgeneem is, openbaar die veelsydigheid van sy wetenskaplike kennis en insig. Dit word gesien in die uiteenlopendheid van hierdie stukke: dic skepping in ses dae, die Geelkerkensaak in Nederland oor die historisiteit van Genesis 1 tot 3 (,Die Sinode van Assen"), Toetank-amen, Jefta se dogter, voedselrantsoenering in die Bybel, Christus 'n advokaat?, neergedaal na die hel, die wederkoms, die ryk van duisend jaar - deurgaans weloorwoë betoë, dikwels met grondige argumentasic en verwysing na erkende wetenskaplike bronne. 
Die veelsydigheid van sy belangstelling en kennis blyk ook uit sy lang artikelreeks oor dic Bybel en boerdery, wat met 'n bykans liriesc artikel oor die paradys begin en waarin hy, amper terloops, uit die beurtsang tussen Adam en Eva in Vondel se Adam in ballangschap aanhaal om die ,skoonheid en volheid" van hierdie lushof te onderstreep. (Hieruit blyk ook dat hy Vondel se drama redelik goed moet geken het, want so iets skiet 'n mens nie sommer vanself te binne nie.) En dan word, hierby aansluitend, onder andere gehandel oor die „skriklike teenstelling" na die sondeval en oor die mens se lyding en stryd op die met sonde deurweekte wêreld, nie alleen in Palestina nie maar ook in Suid-Afrika, waarby 'n mens telkens verras word nie alleen deur die omvang van sy kennis nie maar ook deur die verrassende en skerpsinnige wyse waarop hy dit weergee. Ek verwys maar net na die beginwoorde van die voorlaaste artikel in hierdie reeks, naamlik „Wysheid”, wat handel oor wat in die Sprcukebock oor die onderwerp gesê word. Dit begin met hicrdie ,wysheid":

Wysheid is nie geleerdheid nie. Gelcerdheid moet ons soek in die skole van gelecrdes. Wysheid daarenteen hou verband met die daaglikse lewe. Dit is 'n gawe wat elke mens kan besit, ook al is hy geen geleerde nie. dit is die onmiddellike en regte insig in die natuur en die natuurlike lewensverhoudings. (Ek kursiveer).

Naas die reisverhaal - wat ook meer as reisverhaal is -, Bybellande deurreis, wat ek onder die opskrif „Bakermat” (van die kerk) hier ingesmokkel het, word in deel 2 van die NVW sy artikels en werke oor die kerk saamgevat. Die rubrieke waarin hulle onderverdeel is $-\mathrm{ja}$, onderverdeel kon word -, onderstreep weer eens die veelsydigheid van die skrywer: "Die moeder”, „Strewe na eenheid”, „Reformasie”, ,Wêreldwyd”, „Toekoms".

In die afdeling „Die moeder” kom sulke artikels voor soos „Die 
kerk: moeder van die gelowiges", „Die ecnheid van dic kerk" „Kerk en wêreld", en as 'n mens so deur die eerste stuk blaai, val sy belesenheid en bronbeheersing weer op: Op die cerste bladsy verwys hy na dr. Adolf Keller se Christian Europe today en sien jy hoe hy aanhaal en verwys na bladsye $127,127,158$, $195,199,203,200,188,275-283$. Hierna verwys hy na dr. B. Wielenga: Het wezen van het Christendom, dan na Bavinck: Dogmatiek, IV, bladsy 329; weer na Wielenga, bladsy 245; na Wesley: Works, VIII, bladsy 354; Pope: Higher catechism, bladsy 327; A. Kuyper in die Heraut, nr. 1357; Voctius (uitg. Rutgers, bladsy 27); Wormser, bladsy 2, en weer na Keller, Wielenga, Kuyper, elke keer met bladsyverwysing. Tussendeur is daar nog talle teksverwysings en -verklarings. En bowenal bly dit nie net by wat sy bronne sê nie, maar sy eie opvattings staan duidelik omlyn.

Ek het hier effens uitvoerig verwys om aan te toon dat hy werklik wetenskaplik werk en nie in 'n gemoedelik emosionele opstel oor so 'n onderwerp verval nie.

In die tweede afdeling val 'n sestal artikels oor ekuminiteit en in die derde drie oor die Hervorming, wat eindig met die stemmingsvolle stuk ,Wittenberg”.

Die afdeling „Wêreldwyd" het as temastuk vir die artikels wat oor Suid-Afrika handel, sy „Van Riebeeck-rede” van 1952: „Transformasie soos deur vuur", 'n deurtastende en dikwels digterlike samevatting van die dric ,pakkette" wat Van Riebeeck op sy boot gehad het en wat die grondslag van die Gereformeerde leer en kerk in Suid-Afrika vorm: die Bybel, die Belydenisskrifte en die Psalms.

Verder oor Suid-Afrika handel onder andere sy „Geskiedenis van die Afrikaanse Kerke" asook sy getuienis in die Du Plessis-saak oor inspirasie, die sogenaamde hoër kritiek en die Kenosisleer, wat weer sy geleerdheid en veclsydige kennis toon. 
Dic orige onderafdelings onder hierdie rubrick handel oor die kerk in Nederland, Amerika en elders.

Die laaste afdeling word genoem „Toekoms”, en hieronder val die pragstuk „Ons roeping en toekoms" en die lang en gedeë artikelrceks uit 1929 oor „Die ewige lewe”.

In deel 3 van die NVW is sy studies oor die erediens saamgevat, en ook hieruit blyk die veelsydigheid van sy wetenskaplike arbeid.

Die eerste afdeling word beslaan deur die temastuk van die deel, naamlik Die modelgemeente, wat oorspronklik as artikelreeks in Het Kerkblad verskyn het en oor die jare 1906-1912 versprei was maar ook as afsonderlike boekie verskyn het. Dit is opgestel in die vorm van tweesprake tussen lidmaat, ouderling, leraar, diaken. Merkwaardig is dat in die heel eerste aflewering daar van die Nuwe-Testamentiese lied sprake is as die Ouderling op 'n vraag oor regsinnige gesange antwoord:

Ek meen egter dat daardie gesange uit die Woord van God moet wees; stukke uit die Nuwe Testament moet so letterlik moontlik berym word (bladsy 7).

Hierdie pleit is later verder gevoer, onder andere in 'n artikel in Die Kerkblad van 20 Januarie 1931 waarin hy teen prof. H.H. Kuyper in betoog en bewys dat sulke beryminge moontlik is (NVW 3:439), in die diktaat aan sy studente in 1939 (NVW 3: 425) en in die polemiek met ds. H.J. Venter in 1934 (NVW 3: 444).

Afdeling $\mathbf{B}$ handel oor die ampte en bevat, naas 'n verskeidenheid kortere artikels, ook die omvangryke werk „Oor die amp van ouderlinge en diakens" (1906). In die heel laaste hoofstuk van hierdie werk, waarin hy verskillende aspekte van die twee ampte behandel, bespreek hy - in 1906 reeds! - die vandag nog 
veel besproke vraag of dic diakens ook die kerklike bydrae moet insamel of nie en meteen ook die kwessie van "vrywillige" bydraes tot die kerklike uitgawes, wat in twee ander artikels oor die tiende (1933) verder uitgebou word.

Afdeling $\mathrm{C}$ bevat 'n aantal stukke wat as „Kerkordelik” gerubriseer is, onder andere oor die status van die gemeentevergadering (1918), dic versorging van emerii (1923), die kerklike posisie van die vrou, wat vandag weer/nog op die voorgrond kom (1917, 1935).

In afdeling $\mathrm{D}$ word die stukke saamgegroepeer wat meer in die besonder oor die verkondiging van die Woord en die bediening van die sakramente handel. Oor laasgenoemde is daar 'n uitvoerige behandeling van die nagmaal bestaande uit 18 artikels wat in 1934-1935 in Die Kerkblad verskyn het. In hierdie afdeling is ook opgeneem sy tweede rektorale rede: „Preekmetode” (1916), wat, ten spyte van sy voorbchoud:

Die verleiding is groot om by 'n rektorale oordrag 'n suiwer wetenskaplike onderwerp te kies en dit volgens streng wetenskaplike metode te behandel. Hierdie geleentheid leen hom daartoe om na buite iets te laat blyk van wat jaar in, jaar uit in stille afsondering in die lesingsaal bespreek word; om die swaar voorhangsel weg te skuiwe en dic buitewêreld 'n blik te gun in die binnste heiligdom van die wetenskaplike arbeid.

Ewenwel het ek gemeen dat die verleiding weerstaan moet word en dat ek my keuse moet vestig op 'n meer praktiese onderwerp, hoewel 'n stof na my professorale hart reeds gekies en afgebaken was $(3: 212-3)$.

tog 'n gedeë redevoering word - hy kan amper nie anders as om wetenskaplik te wees nie, ook al bestaan dit net in oorwoë meningsuiting. Hierdie "mening” is juis in velerlei rigting wetenskaplik gevorm. 
Waar in die laaste afdeling, ,het psalm en lied", meer in die besonder oor die kerksang gehandel word, staan 'n mens verstom oor sy uitsprake nie alleen oor die wese en waarde van dic kerksang of oor verstegniese kwessies nie maar selfs ook oor dic melodie en musick van die kerksang.

In verband met verstegniese kwessies is daar een eienaardige uitspraak wat, as ek dit reg begryp, op 'n ongewone wanbegrip by hom dui. Oor 'n nuwe Nederlandse verwerking van die Lofsang van Sagaria maak hy dic opmerking:

Wat vreemd aandoen, is dat die laaste dric reels op mekaar rym maar dat twee 5 voete en een 4 voete het - icts wat ons nêrens anders in dic Psalmboek aantref nic (1923; $3: 352)$.

Dit is nie duidelik wat hy as uitsonderlik beskou nie: dat daar drie rymende reëls is, dat ' $n$ kortere op twee langeres rym of albei nie. As dit gaan om rym van kort op lank, verbaas dit 'n mens dat hy byvoorbeeld Psalm 22 nie raakgesien het nie, waarin dit in elke strofe twee kecr voorkom.

In deel 4 en 5 is eerstens saamgebundel sy preke, onderskeidelik oor Ou-Testamenticse en Nuwe-Testamentiese stof. Oor die preke gesamentlik volstaan ek met die opmerking dat hulle - op miskien een ná, wat ek hier nie nader wil aandui nie - almal getuig van die deeglike wetenskaplike onderlegdheid waaruit hulle spruit en van verrassend heldere insig en inkleding, waaragter naas die wetenskaplike ook die digter staan. 'n Verrassing is dat hierdie vertaler van die Ou Testament meer preke oor die Nuwe Testament gepubliseer het, naamlik 90 teenoor 77 oor die Ou Testa. ment. Wat ook in die besonder opval, is die belangstelling in die apokaliptiese: die enkele boek waaroor die meeste preke gemaak is, is Openbaring, naamlik 26 preke, en dit, tesame met die nege artikels oor „Dic tekens van die tye” en 'n preek soos „Hemelvaart en wederkoms", vorm 'n groot deel van die geheel. Ook opmerkenswaardig is die feit dat 39 van die 167 preke - bykans 
'n kwart - oor stof uit die Evangelies handel. Dit verbaas origens nie dat Jesaja en die Psalms die volgende in die rangorde is nic. Sy groot belangstelling in Jesaja blyk ook uit die twee stukke "Jesaja se openbaringboek" en „Wêreldrevolusie en wereldbou”, twee uitgebreide studies oor hierdie profect.

Oor die Calvinisme het hy verskeie en gegronde artikels geskry'we, waaronder wetenskaplik gesien sy inougurele rede in 1911 oor die sestiende-ceuse ,profesie" seker die hoogste staan. Maar daar is ook nog ander stukke, soos „Calvyn se beginsels", wat sý by. drae was tot dic boekie van hom en ds. T. Hamersma oor Calvyn; „Enkele grondbeginsels van die Calvinisme”, „Calvinisme in SuidAfrika as historiese verskynsel". Maar dan het hy ook oor ander geestestrominge geskryf, naamlik sy proefskrif oor dic Metodisme „Dic Réveil in Nederland”, dic CSV, „I) "Doop van die Gees'”, „Die Spiritisme". En net soos die lang artikelreeks oor die ewige lewe het hy ook 'n reeks oor die hel geskrywe (1925).

$\Lambda$ s' $n$ mens daaraan dink dat Totius grootgeword het in die huis van die leier van dic Genootskap van Regte Afrikaners en die Eerste Afrikaanse Beweging, wat as doelstelling gehad het: "Ons staan vir ons taal, ons nasic en ons land", dan verbaas dit jou nie dat hy in die politiek, met name die Christelike politick, in die taal en in die volk intens belanggestel het nie. In sy ,Jeugherinneringe" - die enigste stuk waarvoor die uitgewers verlof tot opname in die NVW geweier het - sê hy:

Die Patriot-atmosfeer was 'n nasionale asem wat ek steeds met meer welgevalle na binne getrek het,

en in sy openingsrede van die Volksjeugkongres in 1941 by die Oog van Mooirivier, ,Nuwe vorme", verklaar hy dan ook:

Van my jeug af het ek met voorliefde studie gemaak van staatkundige en maatskaplike vraagstukke soos dit by die lig van Gods Woord moet geskied. Alreeds die program 
van beginsels deur my vader vir dic Afrikancrbond ontwerp het my belangstelling galande gemaak. lin in my studictyd was dit vir my 'n lichebbery om die werke van manne soos Groen van Prinsterer en dr. A. Kuyper te bestudeer. Altyddeur, en tot vandag toe, het ek my verlustig in die ideaal dat ons van huis uit Christelike nasie daartoe gelei sal word om in al sy lewensvorme beslis die Christelike waarheid te bely en te belewe (NVW 7:10).

Hierdie belangstelling en licfhebbery is verder en ook wetenskaplik verdicp toe hy rondom 1920 die Staatsleer moes bestudeer om aan die MA-student, II.G. Stoker, leiding te gec.

Teen hierdie agtergrond gesien is dit dan ook geen wonder dat hy oor staat, maatskappy, taal en kultuur soveel geskryf en so baic redevoeringe gehou het nie.

Die bykans 120 stukke oor staatkundige aangelcenthede kan onder enkele hoofde gerubriseer word, wat ook sy veclsydigheid openbaar, te wete Christelike politiek; ideologieë; wêrclddele, lande en volke; oorlog en vrede; nasionale temas en ten slotte die veclvolkigheidsprobleem.

Onder die rubrick "Christelike politiek" ressorteer die reeds genoemde „Nuwe vorme” as ,temastuk”. Daarop volg die artikel uit 1911: „Christelike politiek”, waarin ook die oproep tot verootmoediging voorkom wat in 1901 opgestel en onderteken is deur die voormanne van die twee Republicke: „Schalk W. Burger, Wd. President der Z.A.R.; M.T. Steyn, President O.V.S.; Christiaan de Wet, Komt. Generaal der O.V.S.; Louis Botha, Komt. Generaal der Z.A.R.; J.C. Smuts, Staatsprocureur der Z.A.R. en Asst. Kommandant Generaal der Z.A.R." In die naamlys het hy die naam van generaal Botha swart laat druk, omdat hy dit in die artikel teen die Manifes van generaal Botha het wat moes dien om die, ,groot beginsels van die Program van die S.A. Nasionale Party neer te lê" en waarin die Naam van God nêrens voorkom nie en net van die „Voorsienigheid" gepraat 22 
word. En dan eindig die artikel met die woorde:

Is die generaal Botha van 1901, medeondertekenaar van die stuk, dieselfde generaal Botha van 1911? Dieselfde generaal Botha wat die Manifes uitgevaardig het?

Mannebroeders, Christusgelowiges, wees gewaarsku! (NVW 7:15).

Waar hy oor Christelike politiek skryf, is dit amper vanselfsprekend dat hy dit ook sal hê oor president Kruger (,Die groot figuur” en „Kruger en Cromwell”) en dr. A. Kuyper („Die Kuyperministerie” en „,Dr. Kuyper en die Roomse” - in laasgenoemde verdedig hy Kuyper se koalisie met die Roomse om 'n kabinet saam te stel).

Die 22 artikels oor ideologieë tref deur hulle uiteenlopendheid en omvattendheid, deur die veelsydigheid van sy belangstelling en kennis. Hy handel naamlik onder andere oor Da Costa se besware teen die gees van sy eeu, oor Groen van Prinsterer se opvattinge en praktyk, oor outokrasie en diktatuur, NasionaalSosialisme en Bolsjewisme. Veral oor laasgenoemde het hy baie geskryf, en baie van sy ,voorspellinge" sien ons vandag in vervulling gaan. Reeds in 1919 het hy daarteen gewaarsku, wel nog aarselend, soos uit die volgende woorde blyk:

Noodsaaklik is dit seker dat iets gedoen word. Ons kan tog nie ons Afrikanerwerksman deur die Bolsjewistemonster laat opvreet nie. Ons kan ook nie toelaat dat ons Christelik-Afrikaanse maatskappy stuk vir stuk voor ons oog verteer word nie. Graag verneem ons die opinies van ander hieromtrent (NVW 7:89).

maar in 1942 is die uitkoms vir hom baie helder:

Gaan ons, nou kragtiger as ooit, die Kruisbanier ophef en die Evangeliebasuin laat hoor, sodat die massas in Afrika 
by hul ontwaking uit die slumer dié tekens kan sien en die geluid kan hoor? Of galan ons hulle prysgee aan die propaganda valn die gevreesde Kommunisme? (NVW 7:140).

Oor wêrelddele, lande en volke is daar ook verskillende artikels en van uiteenlopende aard oor die verskillende werclddele, met name Europa, Asië en $\Lambda$ frika, oor die huis van Oranje in Nederland, oor die Verre en Midde-Ooste, die Arabiere, die Heilige Land, maar scker die insiggewendste met betrekking tot sy veelsydigheid en die diepte van insig is dic dricluik ,Drie werelddele”: „Die sterwende Europa”, „I)ie ontwakende Asië”, „Die sluimerende Afrika" (1942).

Die tocstand van oorlog en geen vrede nie selfs al is daar nic oorlog nie, het hom diep gerocr en diep gekwel, en uit hierdic gemoedstoestand van kwelling oor die mensheid het verskillende artikels ontstaan. Baic opmerklik is dit dat van dic 28 artikels wat onder die hoof „Oorlog en vrede" saamgegroepeer is, daar net ses is wat gedurende die verloop van die twee groot wêreldoorloc van hierdic ecu geskryf is, naamlik een in 1916, drie in 1917 , een in 1918 en een in 1943. Vraagstukke wat hom in hierdic stukke besig hou, is onder andere: dic Heilige Skrif en oorlog, die toestand van dic wêreld waar ons in woon, dic gedurige onrus wat voortduur, dic soeke na vrede buite God om.

Ook oor die bestaan van die Afrikanervolk as volk, oor sy wese as volk, sy roeping en sy voortbestaan het hy heelwat geskryf. Ek het as „temastuk" vir hierdie artikels die stuk ,Drome droom" gekies. Hierdie stuk staan in verband met dic ceufecsjaar, die jaar van dic simboliesc Ossewatrek, $\mathrm{en}$ is bedocl as rigtinggewer deur die verwysing na die dromer Josef, wat redder geword het, en die leier Moses, wat wel nic drome gedroom het nic maar van wic geskrywe staan dat hy, ,gewandel het soos een wat die Onsienlike sien". Hieruit puur hy dan die waarheid:

Dic liggestaltes van ons voorgeslag mag alleen gesien word in die lig van God. Met ander woorde ons lig moet terugge- 
lei word na sy bron. In hulleself het die Voortrekkers geen waarde besit nie. Sonder God was hulle net dooie hemelbolle, heeltemal dol, pure materie, enkel stot.

Dic Calvinis dring deur, met die verkyker van die Woord van (iod, in die oncindigheid in, totdat hy die oer-Son, naimlik God, weer vind. As hy God verloor, sou hy miskien die hele stoflike wêreld kan vind, maar hy ly skade aan sy siel. Dic Afrikaner verloor sy siel as hy van God en sy Christus wegswerl. Fakkeldraers in donker Afrika kan ons alleen wees as ons fakkels gevoed word deur die goue olic van dic Heilige Gees.

Wesens- en stemmingsverwant hieraan is ook die volgende artikel, „Verkiesingsbewus” (1943), wat nic met 'n elcksic te make het nic maar met dic uitverkicsing, walarvoor hy na Israel verwys wat 'n ,eiendomsvolk" genoem word, en na uitsprake van Jesaja, wie se ,verkiesingsgeloof" juis in die tyd van die dicpste vernedering van sy volk op die voorgrond gedring word. Hierdic stuk eindig dan met dic twee uitsprake:

'n Volk sonder hart is 'n wolk sonder water, 'n boom sonder vrugte, 'n skip sonder kompas.

Gee aan die Afrikaanse volk weer 'n hart in sy lyf, en felle oortuiging, 'n helder doelbewustheid, 'n roeping van sy God afkomstig en - die volk sal herlewe!

In ander stukke word daarop gewys dat die Afrikanervolk ,,verkeerd getrek" het toe hy soos dic groot volke wou word; dat aanpassing nie uiteraard verkecrd is nie, mits jy aan jou wese getrou bly. Hy skryf oor liefde vir volk en vaderland, roep op tot saamsnoering van kragte, keur vrouestemreg en die vrou se verskyning op dic arbeidsmark af.

Ook oor die veelvolkigheidsprobleem in Suid-Afrika het hy 'n aantal vir sy tyd werklik belangrike stukke gepubliseer. Merk- 
waardig vir my as leek bly nog altyd sy uitspraak van 1923, lank voordat Macmillan met sy winde van verandering gekom het. Die volgende woorde staan in twee opeenvolgende alineas in sy artikel getiteld ,'n Wêreldprobleem”.

Maar laat ons by die persing van die gevaar om ons heen nie vergeet dat die kleurkwessic veel meer as 'n SuidAfrikaanse probleem is nie - dit is 'n wêreldvraagstuk! En dit maak die lewe op aarde des te benouder.

Afrika, altyd bekend as die donker wêrelddeel, as die onbekende kontinent - Afrika het langsaam uit sy ecueslaap ontwaak en het sy swart gelaat aan die wêreld laat sien (NVW 7:346).

Nog stukke hieroor is „,Die godsdienstige grondslag van ons rassebeleid", "Van die noorde af", waarin onder andere hierdic interessante gesigspunt voorkom:

Die Voortrekkers, egte kinders van Afrika, het ons geleer om nie suidwaarts te kyk nie maar om noordwaarts in te trek en Afrika in besit te neem. Dit het benoudheid, bloed en trane gekos, en hulle is selfs bemoeilik deur diegene wat hulle moes gehelp het. Maar hulle het deurgedruk. En vandag sien ons dat die Voortrekkerpolitiek die enigste is wat 'n belofte inhou vir almal wat Afrika as hulle tuiste aangeneem het (1949; NVW 7:349 - ek kursiveer).

En verder is daar nog „Die kleurlyn”, „Die donker horison”, ,'n Donker horison”, „Die witman en Afrika”, ,Donker vooruitsigte”, ,Apartheid", en andere.

Ook die stukke oor maatskappy, taal en kultuur openbaar hierdie verstommende veelsydigheid van sy belangstelling en die verrassende insig in hierdie fasette van die volkslewe.

Vir die afdeling „Volk en taal" is die rede by geleentheid van 26 
die hoeksteenlegging van die Voortrekkermonument in 1938 „Die geruis van die Almagtige”, as „temastuk” gekies, en die versoeking is groot om langer hierby stil te staan, omdat dit so 'n uitmuntende becld bied van die diepte van kennis en insig wat die agtergrond van sy denke vorm, en van die breë vlugte van sy gees asook die digterlike taal waarin dit vergestalt word. Ek moet egter met hierdie enkele aanhaling volstaan:

Ons sien in hulle (die waens van 1938) versinnebeeld die draers van die goudskatte van die Trekkers. Hulle het gedra die Bybel wat donker Afrika nie geken het nie. Met hulle saam het gegaan die skat van hoë sede. By die geklap van van die sweep het die aasvoël weggevlieg en die Christelike wêreldgedagte het sy vlerke fosforesserend oor $u$ ('n?) donker land uitgesprei. Hulle het gedra die blanke moeder en haar kind, iets wat ons donker Suidland nog nie gesien het nie. Ja, die moeder en haar kind in die wildheid dit was die geloofstuk van die Trekker, dit het teweeggebring dat die uittog geen ekspedisie was nie maar 'n Trek. Hulle, dic waens, het die vryheidshoop uitgedra wat altyd met die Afrikaner meegetrek het. Hulle het die kinders van die hoop ingelei in die koninkryk van die hoop! (NVW 7: $385)$.

Tot dieselfde kategorie behoort verder artikels oor volksfeeste, oor volkstaal en volkstaak, die GRA, die Voortrekkerland en Voortrek kervolk.

Dan is daar die stukke oor ekonomiese aangeleenthede soos oor ekonomiese en sosiale stryd, oor „loon wat roep", stakings en twee artikelreekse oor die droogte - een in 1914 en een in 1917 - en dan ook oor reënmaak - almal weer aanduiding van die veelsydigheid van sy belangstelling in die dinge van sy land en volk.

Oor volksvreemde tendense en oor gebeurtenisse en praktyke wat hy as volksgevaarlik beskou, verskyn daar ook 'n hele aantal stuk- 
ke. Eienaardig genoeg stel hy hom vierkantig teen verpligte immunisering, en sy rede is dat die staat nie seggenskap oor die liggaam van die individu het nie. Verder skryf hy oor ,,volksbekering", huwelikswetgewing, egskeiding, lotery en staatslotery, dobbelary, drankmisbruik en -afskaffing, boekesensuur, die "movie", lykverbranding, selfmoord en die begrafnis van 'n selfmoordenaar.

Interessant is sy standpunt oor boekesensuur, wat vandag nog steeds in die gedrang is. Hy staan op die standpunt dat die staat in Calvinistiese lande die erkende plig het om vir die publieke eerbaarheid te sorg. Maar:

Dit spreek vanself dat die staatskontrole in hierdie opsig die ouers nie van hul verpligting onthef nie. Ouers moet weet wat hulle kinders kan lees, al is daar ook vir die publieke lewe streng maatreëls getref. Waar is die Engelse spreuk: „My home is my castle” (my huis is my kasteel). As ons maar meer op hierdie grondwaarheid wou terugval! Oor die wêreld daarbuite kan ons nie baasspeel nie, ons kan net getuig. Maar vanaf die drumpel na binnekant is die ouers regeerders in hul huis en moet, vir sover dit ons betref, die koninkryk van Christus begin. Hier is ons in 'n Bybelse en veilige kasteel (NVW 7:571).

Daar is nie nog 'n tema waarin hy buite die Teologie in sy verskillende fasette om en naas die staatkunde soveel belangstelling geopenbaar, waaroor hy met soveel kennis en insig geskryf en waarvoor hy met soveel gloed geywer het as die onderwys en wetenskapsboefening nie. Meer as veertig jaar lank het hy vir Christelik-nasionale onderwys en Christelike wetenskapsbeoefening die pleit gevoer - van sy eerste openbare optrede van belang anders as predikant, naamlik in die Suzannasaal, Pretoria, in 1908 oor "Christelike onderwys met of sonder dogma", tot in 1948 , toe hy met blydskap van die FAK se voomeme om weer CNO te propageer kennis geneem het, en 1951 , toe hy met die selfstandigwording van die PU vir CHO sy Koers-artikel van 1943 
oor „Wetenskap en twyfel” vir die geleentheid omgewerk en aangepas het.

In hierdie artikels en redevoeringe betoog hy die reg van die Christenouer op Christelike onderwys vir sy kind, meer nog: beklemtoon hy die plig van dié ouer om te sorg dat sy kind Christelike onderwys ontvang. Deur die jare heen het hy met gegronde argumente geredeneer, gekommandeer, gepleit, vermaan, verwyt, die regte en verkeerde met skerpsinnige en skerp redenasies aangetoon - dis onmoontlik om al die verskillende aspekte aan te wys. In die NVW het ek die verskeidenheid probeer rubriseer tot stukke oor Christelike onderwys en wetenskap, Christelik-nasionale onderwys, Onderwyskonferensies, Onderwyswetgewing, Godsdiensonderrig, Kind en jeug, Leerboeke, Onderwys elders en Vreemde vuur - laasgenoemde dic antitetiese, waarin hy teen die evolusionisme en humanisme in onderwys en wetenskap te velde trek.

Dit toon alreeds die ontsagwekkende verskeidenheid en vcelsydigheid, en dan reflekteer dit nog nie die diversiteit wat in die afsonderlike stukke na vore kom nie. En dan word ons telkens opnuut getref deur die logika en diepte van sy betoog asook deur die skerpsinnigheid daarvan. In „Die Heilige Skrif as grondslag van ons onderwys", die rede wat hy in 1918 by geleentheid van die 25ste verjaarsdag van die VVOOZA gelewer het, bewys hy eers vir sy gehoor dat die skool 'n organisme is en nie 'n meganisme nie. En hy sluit die toespraak af met hierdie woorde:

Alle onderwys moet deursuur wees met die Christelike beginsel. Selfs 'n Pestalozzi het in sy „Boek van die moeders" gesê: Laat die moeder God vir die kind in die aanblik van die wêreld wys: ,nou wys sy God vir hom in sy teken-, meet- en rekenwerk; sy wys God vir hom in elkeen van sy kragte". Met ander woorde, God in alle onderwys, ook in teken, meet en reken. 
Hoe kan dit? Waar is die verband? - so vra die twyfelaar. Ek antwoord met 'n teenvraag: Waar is die verband tussen my siel en die punte van my hare? Tog word my hare grys as my siel vol kommer is!

Waar is die verband? In my organisme, in my organiese bestaan. So is dit ook met die onderwys. Die Christendom eis die hele mens - al sy kennis en al sy krag. Daartoe moet hy deur die Christclike skool opgevoed word (NVW 8: 8-9).

Ook in sy talle boekbesprekings sien ons hom as veelsydige wetenskaplike wat met gesag praat oor dic werke wat hy behandel. Dit blyk nie alleen uit die verskeidenheid van die boeke wat hy bespreek nie, maar ook uit die meesterlike wyse waarop hy dit in die reel docn. Uitcraard is die meeste van hulle teologiese werke maar dan oor verskillende fasette van die Teologie en van die kerklike lewe in Suid-Afrika en in die buiteland. Party word uitvoerig bespreck, ander met enkele trekke getipeer. Af en toe is dit selfs 'n letterkundige werk wat behandel word, en word 'n mens verras met 'n kostclike tipering, soos die van Knoppen van Berendien Schuiling, wat met hierdie sin begin:

Die gedigte van Berendien Schuiling straal met 'n sagte glans soos 'n pêrelsnoer.

Net so geniaal maar in ligter luim is die bespreking van Cachet se Sewe duiwels in 1907. Tipies van sy onderlegdheid en wyse van bespreking is die behandeling van Van der Vaart Smit se brosjure oor Karl Barth, waarin dit aanvanklik lyk asof hy Barth aanvaar, maar dan eindig hy met hierdie opmerking:

Of Barth se Neo-Kantiaanse onderbou egter die ,gereformeerde" struktuur sal kan dra, sodat dit nog dieselfde gebou bly, kan ons nou nog nic sê nie. Ons sal eers moet sien (1929; NVW 8:368). 
Waar hy oor mense skryf, is dit ook met die keurige presiesheid van die. wetenskaplike wat die wesenstrekke na vore bring en met verrassende formulering tipeer. Ek volstaan met twee aanhalings:

In die waarderende artikel na aanleiding van die oorlyde van dr. H.C.M. Fourie, mede-Bybelvertaler en vriend, skryf hy:

Ily het sy kennis nie uitgestal soos 'n handelaar met sy handelsware doen nie. Hy het meer gelyk op die groothandelaar wat sy rykdom in 'n groot pakhuis wegbêre (NVW 8:411).

waarmee hy 'n beminlike beskeidenheid na waarde skat. En van sy tydgenootlike digter Leipoldt sê hy:

Sy vroeë môrclied is ons ontwakingsgeskenk.

Die groot werk wat hy op die gebied van lewensbeskrywing gelewer het, is die biografie van sy vader, Ds. S.J. du Toit in weg en werk (1917), wat deels uit opgetekende mededelinge van ds. Du Toit bestaan maar grotendeels uit speurwerk in veral die lêers van Die Patriot, op grond waarvan hy dan nie alleen 'n beeld van ds. Du Toit se lewe en werk laat verrys nie maar dit teen die agtergrond van sy tyd en sy mense so teken en so deeglik annoteer dat dit vandag nog 'n standaardwerk by die studie van die Eerste Beweging is.

$\mathrm{Ek}$ het reeds gemeld dat hy as Bybelvertaler wetenskaplike was en ook dat sy digterlike weergawe van die Psalms meer was as die werk van 'n ,,berymer"; maar ook as digter was hy geleerde wat hom met wetenskaplike diepgang van die wese van die kunswerk rekenskap gegee het. Een van die fynste studies wat hy gelewer het, is „De dichter als ziener" (1911 - in NVW 10 vertaald as inleiding opgeneem), maar ek vermoed dat iemand anders dit in besonderhede sal behandel. 
Met hicrdie helikoptervlug oor dic landskap van sy werksaamhede het ek 'n oorsigtelike hoewel onvolledige beeld probeer bied van die omvang en die verskeidenheid van sy wetenskaplike bedrywigheid. As ek sy beeld in verband met dr. Fourie op homself toepas, sou ek sê dat ook hy die groothandelaar is met ontsaglike rykdomme in sy pakhuis, maar hy het ook die rykdom van die taal gehad om sy rykdom mee uit te stal $\mathrm{en}$ aan te bied. En daarvoor kan ons God nie genoeg dankbaar wees nie.

\section{Hertzog Venter}

